\title{
PENGEMBANGAN MEDIA PEMBELAJARAN MATEMATIKA INTERAKTIF BERBASIS KOMPUTER PADA TOPIK BILANGAN BULAT UNTUK SISWA SD PENDIDIKAN MATEMATIKA FKIP UNRI
}

\author{
Jalinus Jalinus, Jesi Alexander Alim \\ Pendidikan Matematika FKIP Universitas Riau, \\ Pendidikan Guru Sekolah Dasar FKIP Universitas Riau \\ jalinus.lintau@yahoo.com , jesi.alexander@lecturer.unri.ac.id
}

\begin{abstract}
ABSTRAK
Permasalahan yang dihadapi saat ini baik guru maupun siswa dalam belajar matematika antara lain: kurangnya variasi metode mengajar guru dalam penyampaian materi untuk para siswa, masih rendahnya motivasi siswa dalam belajar, minimnya media yang digunakan guru dalam menyampaikan materi. Dari fakta yang didapat, maka tim peneliti mencoba memberikan solusi dari permasalahan tersebut yang tepat adalah melakukan pengembangan bahan ajar/media interaktif berbasis komputer. Tekhnologi komputer dapat dimanfaatkan untuk merancang bahan ajar/media matematika yang interktif. Bahan ajar interaktif berbasis komputer ini menyajikan materi bilangan bulat dengan animasi yang lebih menarik dan menyenangkan untuk operasi hitung kali, bagi, tambah dan kurang. Bentuk penelitian yang dilakukan adalah penelitian pengembangan dengan istilah Research and Development (R \& D). Pengembangan ini dilakukan berpedoman pada karakteristik siswa SD. Jadi mereka lebih cepat menangkap pelajaran dari hal-hal yang kongkret yang dipadukan dengan animasi karena sesuai dengan usia siswa SD. Hasil validasi dari para validator menunjukkan bahan ajar matematika interaktif berbasis computer pada materi bilangan bulat telah valid (bahan ajar telah sesuai dengan yang diharpkan). Hasil uji coba yang dilakukan pada kelas IV SD Babussalam Pekanbaru menunjukkan bahwa bahan ajar interaktif berbasis computer pada materi bilangan bulat sudah praktis, terbukti dari hasil deskripsi dan analisis data yang diperoleh dapat disimplkan bahwa bahan ajar efektif dalam memunculkan aktivitas belajar siswa dan dapat membuat siswa belajar mandiri dan menyenangkan (asyik).
\end{abstract}

Kata Kunci: media interaktif berbasis computer

\section{ABSTRACT}

Problems faced today both teachers and students in learning mathematics, among others: the lack of variation of teaching methods teachers in the delivery of materials for students, still low student motivation in learning, the lack of media used by teachers in delivering the material. From the facts obtained, then the research team tried to provide solutions of these problems is the right to do the development of teaching materials / interactive media-based computer. Computer technology can be utilized to design interactive teaching materials/media. This computer-based interactive teaching material presents digital material with animations that are more interesting and fun for counting times, for, plus and less. The form of research conducted is Research and Development. This development is done based on elementary students' characteristics. So they are quicker to grasp the lessons of concrete matters combined with animation. Validation results 
from expert show that computer-based interactive mathematical teaching materials on integer material have been valid (teaching material has been in accordance with the forbidden). The results of trials conducted in the fourth class of elementary school showed that computer-based interactive learning materials on digital material have been practical. It can be concluded that the teaching materials effective in generating student learning activities and can make students learn independent and fun.

Keyword: interactive media-based computer

\section{PENDAHULUAN}

Pembelajaran matematika adalah proses pemberian pengalaman belajar kepada siswa melalui serangkaian kegiatan yang terencana sehingga siswa memperoleh kompetensi tentang materi matematika yang dipelajari. National Council of Teachers of Mathematics (NCTM) (2000), menjelaskan bahwa pembelajaran matematika yang inovatif memerlukan pemahaman tentang apa yang siswa ketahui dan perlukan untuk belajar dan kemudian memberi tantangan dan mendukung mereka untuk mempelajarinya dengan baik. Ini berarti bahwa perlu adanya inovasi dalam metode pembelajaran. Matematika merupakan ilmu universal yang mendasari perkembangan teknologi modern, mempunyai peran penting dalam berbagai disiplin ilmu dan memajukan daya pikir manusia. Untuk menguasai dan mencipta teknologi di masa depan diperlukan penguasaan matematika yang kuat sejak dini. Mata pelajaran matematika perlu diberikan kepada semua peserta didik mulai dari sekolah dasar untuk membekali peserta didik dengan kemampuan berpikir logis, analitis, sistematis, kritis, dan kreatif, serta kemampuan bekerja sama (Depdiknas, 2008).

Kenyataan yang ada di SD, banyak pendapat dari para siswa yang beranggapan bahwa matematika itu adalah momok dalam aktivitas belajar mengajar di sekolah, padahal tingkat kesulitan suatu jenis atau cabang matematika bukan disebabkan oleh jenis atau cabang matematika itu sendiri, tetapi disebabkan oleh sulit dan kompleksnya fenomena solusinya, diselidiki oleh perumusan dengan menggunakan jenis/cabang matematika tersebut.

Di sekolah dasar kesulitan yang dihadapi siswa sering dilihat pada operasi hitung matematika pada bilangan bulat yaitu operasi/ menggunakan kali, bagi, tambah dan kurang. Kesulitan ini bukan hanya berasal dari siswa itu sendiri 
melainkan bersumber dari luar diri siswa di antaranya cara penyampaiannya materi oleh guru.

Khususnya yang teramati dan fakta yang di dapat dari hasil observasi dan diskusi dengan guru-guru di beberapa SD di Pekanbaru, sebagai berikut:

1. Kemampuan mengajar guru kurang

2. Tidak tersedianya sarana dan prasarana, seperti bahan ajar, media pembelajaran dan tempat penyimpanan media

3. Motivasi siswa relatif rendah dan perhatian orang tua juga rendah

4. Guru kurang kreatif membuat/menciptakan media pembelajaran. Walaupun beberapa orang guru sudah memiliki laptop, tapi tidak pernah digunakan untuk menyajikan materi pembelajaran.

5. Proses pembelajaran yang bersifat monoton yaitu guru menyampaikan materi tanpa menggunakan media, memberi contoh soal dan membahas soal-soal (berpusat pada guru).

Salah satu aspek dalam metode pembelajaran adalah penggunaan media interaktif sebagai alat bantu mengajar. Inovasi media interaktif pembelajaran dapat meningkatkan kualitas pembelajaran yang inovatif.

Media interaktif dalam pembelajaran merupakan suatu alat bantu yang digunakan untuk menyampaikan pesan atau informasi kepada peserta didik dalam kegiatan pembelajaran. Hal itu sebagaimana dikemukakan oleh John D. Latuheru (1988: 14) bahwa media pembelajaran merupakan suatu alat bantu yang digunakan dalam kegiatan belajar mengajar, dengan maksud untuk menyampaikan isi atau materi pembelajaran dari sumber belajar kepada peserta didik. Perkembangan ilmu pengetahuan dan teknologi (IPTEK) menuntut guru untuk menggunakan teknologi, khususnya komputer, dalam pembelajaran (Permen Nomor 74 tentang Guru, 2008). Penggunaan komputer sebagai media pembelajaran sebaiknya dibuat interaktif, karena akan mendorong partisipasi siswa sehingga dapat memaksimalkan proses pembelajaran (Suherman, 2009). Yang dimaksud interaktif dalam komputer, yaitu adanya interaksi antara siswa (pengguna) dan komputer misalnya, apabila komputer menayangkan suatu pertanyaan maka siswa dapat menjawab pertanyaan pada komputer dan jawaban siswa akan direspon langsung oleh komputer. 
Berdasarkan uraian di atas maka pengembangan media interaktif berbasis komputer sebagai alternatif media pembelajaran dirasa perlu karena sesuai dengan karakteristik siswa kelas IV yang menyukai kartun atau animasi. Media interaktif yang memasukkan unsur animasi dalam penyajian materi sangat menarik bagi anak karena sesuai dengan karakteristik anak yang senang dengan animasi atau kartun.

\section{METODE PENELITIAN}

Bentuk penelitian yang dilakukan adalah penelitian pengembangan dengan istilah Research and Development ( $R$ \& $\mathrm{D}$ ). Model pengembangan yang digunakan adalah model pengembangan prosedural, yaitu model yang bersifat deskriptif, menggariskan langkah-langkah yang harus diikuti untuk menghasilkan produk. Penulis menitikberatkan pada pengembangan media pembelajaran matematika berbasis komputer untuk materi bilangan bulat berupa buku dan CD.Menurut Sugiyono (2007) langkah-langkah pengembangan penelitian ini (1) Studi literature dan pengumpulan data (analisis awal); (2) Melakukan perencanaan (desain alat peraga dan perangkat pendukung); (3) Mengembangkan produk awal (validasi ahli dan revisi); (4) Melakukan uji coba terbatas.

\section{Prosedur Pengembangan}

a. Studi literatur dan pengumpulan data (analisis awal)

Pada tahap awal untuk mendapatkan gambaran kondisi lapangan (tahap analisis kebutuhan) untuk mendapatkan data tersebut langkah-langkah yang dilakukan adalah sebagai berikut :

1) Melakukan wawancara dengan guru SD bertujuan untuk mengetahui masalah, hambatan ataau fenomenaapa saja yang dihadapi dalam pembelajaran matematika khususnya pada materi bilangan bulat.

2) Menganalisis silabus, RPP mata pelajaran matematika khususnya materi bilangan bulat. Bertujuan untuk mengetahui yang diajarkan sesuai dengan standar kompetensi dan kompetensi dasar pada kurikulum $2013 \mathrm{KI}$ dan KD namanya (Kompetensi Inti dan Kompetensi Dasar).

3) Mengalisis buku-buku teks matematika yang digunakan bertujuan untuk melihat isi buku, langkah penyajian, soal-soal latihan dan tugas-tugas yang 
tertera didalambuku tersebut apakah sudah sesuai dengan kurikulum atau silabus mata pelajaran.

4) Mereview literature tentang bahan ajar matematikasebagai rujukan atau referensi tentang bagaimana membuatmedia yang baik untuk menyampaikan materi bilangan buat sesuai dengan karakteristik siswa kelas IV SD.

b. Melakukan perencanaan (desain alat peraga dan perangkat pendukung)

Hasil dari analisis awal (Kebutuhan) digunakan untuk merancang prototype model media matematika interaktif berbasis komputer pada materi bilangan bulat yang bertujuan untuk dapat membuat media berbasis komputer yang sesuai dengan karakteristik siswa SD.

c. Mengembangkan produk awal (validasi ahli dan revisi)

Kegiatan ini bertujuan untuk mendapatkan hasil produk yang berupa media yang sesuai degan kebutuhan validasi (penilaian) yang dilakukan pakar, apakah media yang telah dirancang sesuai dengan silabus mata pelajaran matematika.

\section{Penilaian Produk}

\section{a. Uji Coba}

Uji coba dilakukan untuk mendapatkan data yang digunakan sebagai dasar utuk merevisi produk. Sebelum diuji cobakan, produk dievaluasi oleh beberapa ahli. Uji coba kelompok kecil produk akan dilaksanakan di salah satu SD di Pekanbaru. Uji coba lapangan dilakukan setelah mendapat validasi dari ahli dan masukan yang diperoleh dijadikan sebagai dasar untuk merevisi produk. Tujuan dari uji coba produk adalah untuk mengetahui kelayakan dari media pembelajaran yang dikembangkan. Selanjutnya mengacu pada batasan dan kriteria bahan ajar dan media yang baik maka aspek-aspek yang menjadi penilaian untuk menguji validasi dalam penelitian ini dimuat pada Tabel 1 berikut. 


\section{Tabel 1}

Aspek Penilaian Terhadap Bahan Ajar dan Media Pembelajaran

\begin{tabular}{|c|l|}
\hline Item & \multicolumn{1}{c|}{ Aspek Penilaian } \\
\hline Bahan & $\begin{array}{l}\text { 1. Format, Sistematika Penyajian, Keterbacaan, } \\
\text { Kejelasan/ Desain objek. }\end{array}$ \\
& $\begin{array}{l}\text { 2. Isi sesuai dengan urutan penyajian dalam } \\
\text { kurikulum, Memuat latihan yang cukup dan } \\
\text { sesuai konsep, Struktur penyajian konsep. }\end{array}$ \\
\hline Media & $\begin{array}{l}\text { 1. Kesesuaian dengan kurikulum } \\
\text { 2. Kesesuaian dengan konsep } \\
\text { 3. Kesesuaian dengan pendekatan karakteristik } \\
\text { siswa SD }\end{array}$ \\
& $\begin{array}{l}\text { 4. Mudah digunakan } \\
\text { 5. Kejelasan objek gambar media }\end{array}$ \\
\hline
\end{tabular}

b. Subyek Uji Coba

Subyek ujicoba terbatas ini dilakukan pada siswa kelas IV SD Babussalam Pekanbaru.

c. Jenis Data

1) Data Kualitatif. Data ini diperoleh berdasarkan tanggapan dan saran tentang pengembangan produk media pembelajaran dari pakar/ ahlii media dan ahli materi.

2) Data Kuantitatif. Data ini diperoleh berdasarkan angket evaluasi media pembelajaran oleh guru matematika SD dan lembartanggapan siswa.

d. Instrumen Pengumpulan Data

Instrumen pengumpul data pada penelitian adalah angket validasi. Data penelitian dikumpulkan dengan meminta validator memberikan penilaian setiap aspek penilaian yang dimuat dalam lembar validasi. Angket validasi yang digunakan dalam penelitian berupa angket validasi media oleh ahli media, angket validasi media oleh ahli materi, angket validasi materi oleh guru, dan angket respon siswa, pada tabel berikut. 
Tabel 2

Kriteria Penilaian Terhadap Bahan Ajar

\begin{tabular}{|l|c|c|c|c|c|c|c|c|}
\hline \multirow{2}{*}{ Aspek yang dinilai } & \multicolumn{7}{|c|}{ PENILAIAN } \\
\cline { 2 - 9 } & SS & S & KS & TS & SB & B & KB & TB \\
\hline & $\mathbf{4}$ & $\mathbf{3}$ & $\mathbf{2}$ & $\mathbf{1}$ & $\mathbf{4}$ & $\mathbf{3}$ & $\mathbf{2}$ & $\mathbf{1}$ \\
\hline Sesuai Kurikulum & & & & & & & & \\
\hline Sesuai dengan konsep & & & & & & & & \\
yang dijelaskan & & & & & & & & \\
\hline $\begin{array}{l}\text { Memuat latihan yang cukup } \\
\text { dan sesuai konsep }\end{array}$ & & & & & & & & \\
\hline Struktur penyajian konsep & & & & & & & & \\
\hline Sistematika penyajian & & & & & & & & \\
konsep/materi & & & & & & & & \\
\hline Keterbacaan & & & & & & & & \\
\hline Desain objek yang menarik & & & & & & & & \\
\hline
\end{tabular}

Ket: SS: Sangat Sesuai, S: Sesuai, TS: Tidak Sesuai, SB: Sangat Baik, B: Baik, KB: Kurang Baik, TB: Tidak Baik.

Tabel 3

Kriteria Penilaian Terhadap Media Pembelajaran

\begin{tabular}{|l|c|c|c|c|c|c|c|c|}
\hline \multirow{2}{*}{ Aspek yang dinilai } & \multicolumn{7}{|c|}{ PENILAIAN } \\
\cline { 2 - 9 } & SS & S & KS & TS & SB & B & KB & TB \\
\cline { 2 - 8 } & $\mathbf{4}$ & $\mathbf{3}$ & $\mathbf{2}$ & $\mathbf{1}$ & $\mathbf{4}$ & $\mathbf{3}$ & $\mathbf{2}$ & $\mathbf{1}$ \\
\hline $\begin{array}{l}\text { Kesesuaiandengan } \\
\text { kurikulum }\end{array}$ & & & & & & & & \\
\hline Kesesuaian dengan konsep & & & & & & & & \\
\hline Kesesuaian dengan strategi & & & & & & & & \\
\hline $\begin{array}{l}\text { Mudah digunakan objek gambar } \\
\text { Kejelasan objen } \\
\text { media }\end{array}$ & & & & & & & & \\
\hline
\end{tabular}

(Diadaptasi dari Sehatta, 2015)

\section{Teknik Pengumpulan Data}

a) Literatur

Literatur digunakan sebagai acuan maupun sebagai penguat data penelitian.

b) Angket

Angket evaluasi terdiri dari empat macam, yaitu angket evaluasi oleh ahli media, ahli materi, guru dan angket respon siswa. 


\section{Teknik Pengolahan dan Analisis Data}

Teknik analisis data dilakukan untuk menentukan seberapa valid dan praktilitas media pembelajaran matematika interaktif berbasis komputer pada topik bilangan bulat untuk siswa SD.

$$
\bar{M}_{v}=\frac{\sum_{i=1}^{n} \bar{V}_{i}}{n}
$$

(diadaptasi dari Sudijono, 2011)

Keterangan:

$\bar{M}_{v} \quad$ : rata-rata total validitas

$\bar{V}_{i} \quad$ : rata-rata validasi validator ke- $i$

$n \quad$ : banyaknya validator

Penentuan rentang dapat diketahui melalui skor tertinggi dikurang skor terendah dibagi dengan skor tertinggi. Berdasarkan penentuan rentang tersebut diperoleh rentang 0,75. Adapun kriteria validitas analisis rata-rata yang digunakan dapat dilihat pada tabel berikut.

\section{Tabel 4}

Kriteria Validasi Analisis Rata-Rata

\begin{tabular}{|c|c|}
\hline Interval & Kategori \\
\hline $3,25 \leq \bar{x}<4$ & Sangat Valid \\
$2,50 \leq \bar{x}<3,25$ & Valid \\
$1,75 \leq \bar{x}<2,50$ & Kurang Valid \\
$1,00 \leq \bar{x}<1,75$ & Tidak Valid \\
\hline
\end{tabular}

\section{PEMBAHASAN HASIL PENELITIAN}

Tujuan penelitian ini adalah membuat media pembelajaran matematika bilangan bulat interaktif berbasis komputer yang valid dan praktis serta meningkatkan aktivitas siswa dalam pembelajaran.

a. Validitas bahan ajar materi bilangan bulat interaktif berbasis komputer

Hasil deskripsi validator menunjukkan bahwa bahan ajar matematika bilangan bulat interaktif berbasis komputer yang dibuat sudah valid dengan melakukan perbaikan-perbaikan sesuai saran validator. Hasilnya dapat dilihat pada Tabel 4 berikut. 
Tabel 5

Hasil Validasi Media Pembelajaran

\begin{tabular}{|c|l|c|c|l|}
\hline No & \multicolumn{1}{|c|}{ Validator } & Jumlah & Rata-rata & Keterangan \\
\hline 1. & Validator 1 & 90 & 3.3 & Sangat Valid \\
2. & Validator 2 & 100 & 3.7 & Sangat Valid \\
3. & Validator 3 & 103 & 3.8 & Sangat Valid \\
\hline
\end{tabular}

Hasil validasi media pembelajaran berbasis komputer model interaktif pada materi pokok bilangan bulat dinilai telah valid oleh ketiga validator. Hasil validasi media pembelajaran dari ketiga validator diperoleh rata-rata sebesar 3.6 dengan keterangan sangat valid, sehingga validator menyarankan untuk diuji coba dengan syarat perbaikan diantaranya:

a. Tujuan pembelajaran harus ada di buku petunjuk

b. Gunakan istilah yang konsisten.

Berdasarkan saran dan pendapat dari validator maka dilakukan revisi sebagai berikut:

a. Pada buku petunjuk ditambah tujuan pembelajaran (serta yang ada pada CD)

b. Menggunakan istilah dan simbol yang konsisten (khusus)

Isi bahan ajar telah sesuai dengan materi pembelajaran yang ada pada buku teks dan silabus mata pelajaran matematika SD kelas IV. Hal ini memang dapat dipastikan karena dalam penyusunan materi bahan ajar mengacu pada buku teks yang dipakai guru dan kurikulum pembelajaran matematika SD kelas IV. Karakteristik bahan ajar juga sudah sesuai dengan bahan ajar interaktif, yaitu dapat merespon serta umpan balik pada siswa dalam pembelajaran. Media berbasis interaktif ini membuat siswa belajar mandiri karena dapat menggali ideide inovatif dalam pembelajaran, sehingga proses pembelajaran berpusat pada siswa.

c. Praktikalitas bahan ajar materi bilangan bulat interaktif berbasis computer

Dari hasil wawancara dan lembar tanggapan siswa, serta hasil observasi pelaksanaan pembelajaran yaitu tentang bahan ajar matematika bilangan bulat interaktif berbasis komputer ini dapat disimpulkan bahwa bahan ajar matematika bilangan bulat interaktif berbasis komputer ini sudah praktis, dapat dibuktikan dengan: 
a) Hasil observasi pelaksanaan pembelajaran matematika bilangan bulat interaktif berbasis komputer dari pertemuan pertama sampai pertemuan keempat diperoleh bahwa proses belajar-mengajar selalu meningkatkan antusias siswa dalam mengikuti pembelajaran (siswa bersemangat dan merasa senang) dapat terlihat pada perilaku siswa dan dapat ditunjukkan berdasarkan data yaitu setiap pertemuan siswa dapat menyelesaikan pembelajaran tepat waktu (beberapa orang yang terlambat). Bahan ajar berbasis komputer ini betul-betul membantu siswa belajar mandiri.

b) Hasil wawancara dan lembar tanggapan siswa terhadap penggunaan media pembelajaran matematika interaktif berbasis komputer pada topik bilangan bulat, rata-rata jawaban siswa adalah:

1) Belajar menggunakan media berbasis komputer untuk topik bilangan bulat sangat menarik dan menyenangkan sehingga mudah mengerti dalam pembelajaran.

2) Belajar dengan media komputer membuat siswa lebih aktif daripada belajar dengan media yang pernah digunakan guru selama ini.

3) Belajar dengan media komputer membuat mereka belajar mandiri.

4) Belajar dengan media komputer membuat mereka menguasai pelajaran matematika dengan cepat.

5) Desain bahan ajar menarik, sehingga waktu yang digunakan sesuai dengan yang telah ditentukan oleh guru.

Dari hasil wawancara dan lembar tanggapan siswa dapat disimpulkan bahwa penggunaan bahan ajar matematika interaktif berbasis komputer untuk topik bilangan bulat sudah praktis terlihat pada tanggapan siswa dan hasil wawancara.

d. Efektivitas Bahan Ajar Matematika Berbasis Komputer

Aktivitas siswa selama proses pembelajaran bilangan bulat interaktif berbasis computer yang diamati oleh observer yaitu: 
Tabel 6

Data Hasil Pengamatan Observer Terhadap Aktivitas Siswa dalam pembelajaran Bilangan Bulat Interaktif Berbasis Komputer

\begin{tabular}{|c|c|c|c|c|c|c|}
\hline \multirow[t]{2}{*}{ No } & \multirow[t]{2}{*}{ Aspek yang diamati } & \multicolumn{4}{|c|}{ Pertemuan } & \multirow{2}{*}{$\begin{array}{l}\text { Rata- } \\
\text { rata }\end{array}$} \\
\hline & & I & II & III & IV & \\
\hline 1 & Memulai kegiatan & 65 & 80 & 90 & 100 & 83.75 \\
\hline 2 & $\begin{array}{l}\text { Kreativitas siswa dalam proses } \\
\text { pembelajaran }\end{array}$ & 80 & 90 & 100 & 100 & 92,5 \\
\hline 3 & $\begin{array}{l}\text { Mencermati gambar/animasi } \\
\text { yang digunakan dalam } \\
\text { pembelajran }\end{array}$ & 90 & 100 & 100 & 100 & 97,5 \\
\hline 4 & $\begin{array}{l}\text { Melihat hubungan konsep } \\
\text { dengan soal yang dikerjakan }\end{array}$ & 85 & 95 & 90 & 90 & 90 \\
\hline 5 & Berdiskusi dengan teman & 80 & 60 & 45 & 50 & 58,75 \\
\hline 6 & Mengobrol di luar materi & 0 & 0 & 0 & 0 & \\
\hline 7 & $\begin{array}{l}\text { Menyelesaikan pembelajaran } \\
\text { tepat waktu }\end{array}$ & 80 & 95 & 90 & 90 & 88,75 \\
\hline
\end{tabular}

Dari hasil lembar observasi terlihat selama pembelajaran menunjukkan bahan ajar dapat memunculkan aktivitas yang positif bagi siswa (menyenangkan). Aktivitas yang sering muncul dalam proses pembelajaran adalah siswa mencermati/mengamati gambar/animasi yang digunakan dalam pembelajaran. Dengan kata lain keuntungan menggunakan komputer dalam pembelajaran dapat meningkatkan kualitas tampilan sehingga siswa dapat melihat konsep yang lebih sempurna yang memungkinkan siswa untuk menggali ide-ide yang cemerlang. Aktivitas siswa yang sangat menonjol adalah waktu mencermati hubungan konsep dengan soal yang dikerjakan sehingga membuat mereka kreatif dalam menyelesaikan soal yang diberikan dengan benar.

\section{SIMPULAN DAN SARAN}

\section{Simpulan}

Bahan ajar/media pembelajaran matematika interaktif berbasis computer pada topik bilangan bulat untuk siswa SD telah diujicoba dan disimpulkan dengan hasil sebagai berikut:

1. Hasil validasi dari para validator menunjukkan bahwa bahan ajar matematika interaktif berbasis computer pada topic bilangan bulat untuk siswa SD kelas IV telah valid. Hal ini berarti bahan ajar tersebut telah sesuai dengan apa yang diharapkan. 
2. Hasil uji coba yang dilakukan di kelas IV SD Babussalam Pekanbaru menunjukkan bahan ajar interaktif berbasis computer pada topik bilangan bulat sudah praktis.

3. Berdasarkan deskripsi dari analisis data dari wawancara dan lembar tanggapan siswa dapat disimpulkan bahwa bahanajar efektif dalam memunculkan aktivitas belajar siswa.

\section{Saran}

1. Bahan ajar matematika interaktif berbasis computer pada topik bilangan bulat dapat dipakai untuk membantu pembelajaran di kelas IV SD khususnya di SD Babussalam Pekanbaru.

2. Bahan ajar matematika interaktif berbasis computer pada topik bilangan bulat dapat dipakai untuk membantu siswa belajar mandiri di sekolah atau di rumah.

3. Bahan ajar matematika interaktif berbasis computer padatopik bilangan bulat dapat dijadikan sebagai contoh untuk mengembangkan bahan ajar interaktif untuk topic matematika yang lain.

\section{DAFTAR PUSTAKA}

Anas Sudijono. 2011. Pengantar Statistik Pendidikan. Rajawali Press.Jakarta.

Daryanto. 2011. Media Pembelajaran. Nurani Sejahtera. Bandung.

Depdiknas, 2004, Kurikulum 2004 (StandarKompetensi) Depdiknas. Jakarta.

Hasnul. 2011. "Desain Media Pembelajaran Animasi Berbasis Adobe Flash CS3 pada Mata Kuliak Instalasi Listrik 2". Jurnal Medtek, 2:5-6

Lasmadi dan Nur Salihah. 2012. Pengembangan Bahan Ajar Mateatika Interaktif Berbasis Komputer pada Topik Lingkaran untuk Siswa Kelas VIII MTs. Dalam Seminar Nasional Matematika dan Pendidikan Matematika 2012. Padang.

John D. Latuheru. (1988). Media Pembelajaran dalam Proses Belajar Mengajar Masa Kini. Jakarta: Depdikbud.

Made Wena. 2011. Strategi Pembelajaran Inovatif Kontemporer, Suatu Tinjauan Knseptual Operasional. Bumi Aksara. Jakarta.

Malalina. 2009. Pengembangan bahan ajar interaktif berbasis computer pokok bahasan lingkaran untuk kelas VIII sekolah menengah pertama. 
(http://file.upi.edu/Direktori/FIP/JUR/makalahPengembanganbahanajarintera ktif berbasis computer pokok bahasan lingkaran untuk kelas VIII sekolah menengah pertama belajaran.pdf) diakses 5 Juni 2017.

National Council of Teachers of Mathematics (NCTM). (2000). Principles standards and for school mathematics. Reston: NCTM, Inc

Sehatta, S. dkk.2015.Pengembangan Bahan Ajar dan Media Pembelajaran Matematika. Pekanbaru: FKIP UR Tidak diterbitkan.

Sugiyono.2007. Metode Penelitian kuantitatif, Kualitatif dan R \& D, Bandung: Alfabeta.

Suherman, Yuyus.2009.Pengembangan Media Pembelajaran bagi ABK.

(http://file.upi.edu/Direktori/FIP/JUR/makalahpengembanganmediapembelaja ran.pdf) diakses 5 Juni 2017

Suharsimi Arikunto. 2004. Evaluasi Program Pendidikan. Bumi Aksara.

Yansen Marpaung. 2006. Karakteristik PMRI (Pendidikan Matematika Realistik Indonesia). Jurnal Pendidikan Matematika MATHEDU. 1(1). PPS UNSA. Surabaya. 